\title{
EVALUASI PELATIHAN (TRAINING) LEVEL II BERDASARKAN TEORI THE FOUR LEVELS KIRKPATRICK
}

\author{
Umi Widyastuti \\ Fakultas Ekonomi Universitas Negeri Jakarta \\ umiwidyastuti_feunj@unj.ac.id \\ Dedi Purwana ES \\ Fakultas Ekonomi Universitas Negeri Jakarta \\ dpurwana@unj.ac.id
}

\begin{abstract}
Training is an important aspect in human resources development (HRD) in the organization, as an effort to improve knowledge, skills, and expertise. It should be organize effectively in accordance with the needs of the organization's member.This research was conducted to evaluate the training for students organized by PusatSumber BelajarUniversitas Negeri Jakarta (PSB UNJ); and it aimed to find out the effectiveness of training at level II, based on the theory of Four Levels Kirkpatrick. The training that we observed in this study includingtraining of scientific approach learning, training of project-based learning, training of internet based learning, training of simple medium and training of authentic assessment. Population in this study is all students who participate in these programs that came from the entire faculty in UNJ. Using purposive sampling, the sample is randomly selected proportionately based on the type of training provided by PSB UNJ. The number of samples obtained is 110 students.By comparing pre and post-testdata using paired samples t-test, the resultsshown that there are significant difference in knowledge and skills before and after attending the training.
\end{abstract}

Keyword: scientific approach, project based learning, authentic assessment

\begin{abstract}
ABSTRAK
Pelatihan merupakan aspek penting dalam pengembangan sumberdaya manusia (SDM) pada organisasi, sebagai upaya untuk meningkatkan pengetahuan, keterampilan, dan keahlian. Ini harus diatur secara efektif sesuai dengan kebutuhan anggota organisasi. Penelitian ini dilakukan untuk mengevaluasi pelatihan bagi siswa yang diselenggarakan oleh Pusat Sumber Belajar Universitas Negeri Jakarta (PSB UNJ); dan bertujuan untuk mengetahui keefektifan pelatihan di tingkat II, berdasarkan teori Four Levels Kirkpatrick. Pelatihan yang kami amati dalam penelitian ini mencakup pelatihan pembelajaran berbasis sains, pelatihan pembelajaran berbasis proyek, pelatihan pembelajaran berbasis internet, pelatihan media sederhana dan
\end{abstract}


pelatihan penilaian otentik. Populasi dalam penelitian ini adalah semua siswa yang berpartisipasi dalam program ini yang berasal dari seluruh fakultas di UNJ. Dengan menggunakan purposive sampling, sampel dipilih secara acak berdasarkan jenis pelatihan yang diberikan oleh PSB UNJ.Jumlah sampel yang diperoleh adalah 110 siswa. Dengan membandingkan data pra dan pasca pengujian data menggunakan uji-t berpasangan, hasil penelitian menunjukkan adanya perbedaan pengetahuan dan keterampilan yang signifikan sebelum dan sesudah mengikuti pelatihan.

Kata kunci: Pendekatan ilmiah, Pembelajaran berbasis Proyek, Penilaian otentik

\section{PENDAHULUAN}

Pelatihan atau training merupakan aspek penting dalam upaya pengembangan sumberdaya manusia, yang dapat berpengaruh secara langsung maupun tidak langsung terhadap kinerja orga-nisasi baik untuk organisasi profit oriented maupun nonprofit oriented. Sumberdaya manusia (SDM) yang ada di dalam organisasi merupakan sumberdaya yang memiliki kemampuan untuk mengelola sumberdaya lainnya dalam mendukung tercapainya tujuan sebuah organisasi. Oleh karena itu, SDM harus dikelola secara baik dengan memberikan bekal pengetahuan, keterampilan, dan keahlian yang lebih dan sesuai dengan kebutuhan.

Salah satu cara yang dapat dilakukan oleh perusahaan dalam upaya peningkatan, pengembangan, dan pembentukan sumberdaya manusia dilakukan melalui pendidikan dan pelatihan. Pelatihan pada hakikatnya meng-andung unsur-unsur pembinaan dan pendidikan. Pelatihan merupakan suatu fungsi manajemen yang perlu dilaksanakan terus-menerus dalam rangka pembinaan sumberdaya manusia dalam suatu organisasi.
Secara spesifik, proses pelatihan merupakan serangkaian tindakan atau upaya yang dilaksanakan secara berkesinambungan, bertahap dan terpadu.

Penyelenggaraan pelatihan dalam suatu organisasi tidak bisa dipungkiri membutuhkan dana, waktu dan tenaga yang tidak sedikit. Oleh karena itu, manajemen yang memiliki wewenang dalam pengambilan keputusan perlu mengetahui bahwa pelatihan merupakan sebuah investasi yang dikeluarkan oleh organisasi tersebut.

Untuk meyakinkan pihak pengambil keputusan bahwa suatu program pelatihan merupakan investasi, maka tidaklah cukup hanya dengan memaparkan segisegi persiapan, teknis pelaksanaan dan hasil perubahan perilaku yang diharapkan terjadi setelah peserta mengikuti pelatihan tersebut. Hal yang perlu diperhatikan adalah bagaimana membuat organisasi tersebut dapat memahami bahwa penyelenggaraan pelatihan bukan sebagai expense (pengeluaran) tetapi benar-benar merupakan sebuah investasi yang memiliki pengaruh signifikanterhadap peningkatan kinerja atau kompetensi 
anggota organisasi sehingga lebih berkualitas dalam mendukung pencapaian tujuan serta visi dan misi organisasi.

Untuk mengetahui hasil, dampak maupun manfaat yang diperoleh dari pelatihan yang diberikan kepada karyawan maka perlu dilakukan evaluasi terhadap setiap pelatihan tersebut. Setelah pelatihan diberikan, tentunya perlu diketahui sejauhmana kontribusi pelatihan tersebut terhadap perubahan atau peningkatan kinerja maupun kompetensi terhadap masing-masing anggota organisasi maupun terhadap organisasi secara keseluruhan. Hal ini penting mengingat bahwa belum tentu sebuah pelatihan yang diberikan dan telah menyerap dana besar selalu memberikan hasil yang efektif sesuai dengan tujuan pelatihan yang ingin dicapai oleh perusahaan.

Secara umum tujuan pelatihan menurut Noe (Noe, 2009) adalah meningkatkan pengetahuan (knowledge), keterampilan (skill) maupun perilaku (attitude) agar para karyawan dapat menjalankan fungsi dan tugas jabatannya secara optimal.

PSB UNJ merupakan salah satu unit yang memberikan pelayanan kepada mahasiswa dan tenaga pendidik di lingkungan UNJ dalam bidang pelatihan terkait dengan kompetensi yang harus dimiliki oleh pesertanya.PSB UNJ telah menyelenggarakan pelatihan secara rutin dan senantiasa melakukan perbaikan guna menanggapi tuntutan perubahan di lingkungan eksternal melalui penyediaan tenaga pelatih yang handal, materi pelatihan yang terbarui dan metode pelatihan yang menarik.Berdasarkan pengamatan yang dilakukan, PSB UNJ belum secara optimal melakukan evaluasi terhadap pelatihan yang telah dilakukan. Evaluasi pelatihan adalah upaya untuk mengetahui tingkat keterlaksanaan program, atau untuk mengetahui implementasi dari suatu kebijakan. Dengan demikian kegiatan evaluasi pelatihan mengacu pada tujuan sebagai ukuran keberhasilan.

Implementasi program harus senantiasa dievaluasi untuk melihat sejauh mana program tersebut telah berhasil mencapai tujuan pelaksanaan program yang telah ditetapkan sebelumnya. Tanpa adanya evaluasi, pelatihanpelatihan yang telah dilaksanakan tidak akan dapat dilihat efektifitasnya. Dengan demikian, kebijakan-kebijakan baru sehubungan dengan program tersebut, tidak didukung oleh data. Oleh karena itu, evaluasi pelatihan bertujuan untuk menyediakan data dan informasi serta rekomendasi bagi pengambil kebijakan (decision maker) untuk memutuskan apakah akan melanjutkan, memperbaiki atau menghentikan sebuah program. Selain itu evaluasi dimaksudkan untuk mengukur efektifitas keberhasilan penyelenggaraan pelatihan. Berdasarkan latar bela-kang tersebut, dianggap perlu dilakukan penelitian tentang evaluasi pada pelatihan yang telah diselenggarakan oleh PSB UNJ dengan membatasi pada evaluasi level II menurut teori The Four Levels yang dikembangkan oleh Kirkpatrick. 
KAJIAN TEORITIK

Noe and Tews (Noe, 2009) menjelaskan tahapan stratejik dalam pelatihan dan pengembangan pada sebuah organisasi seperti digambarkan pada gambar 1.Tahapan dimulai dengan mengidentifikasi strategi bisnis. Dengan melakukan identifikasi strategi bisnis maka dapat diketahui kebutuhan karyawan akan pelatihan. Berdasarkan analisis kebutuhan tersebut, tahap selanjutnya adalah bahwa menentukan tujuan stratejik dari pelatihan dan pengembangan yang akan diselenggarakan oleh perusahaan untuk mendukung pencapaian strategi bisnis.
Selanjutnya tahap ketiga adalah menterjemahkan hasil identifikasi strategi bisnis dalam bentuk kegiatan pelatihan.Kegiatan pelatihan dapat mencakup pembelajaran formal dan informal dengan memanfaatkan berbagai jenis metodologi tradisional maupun yang terbaru. Tannenbaum (2002) menyatakan bahwa pelatihan dan pengembangan sebaiknya bersifat unik tergantung pada keunikan tujuan dan tantangan masingmasing organisasi.Tahap terakhir adalah melakukan evaluasi untuk memastikan apakah pelatihan memberikan kontribusi dalam pencapaian tujuan organisasi atau tidak.

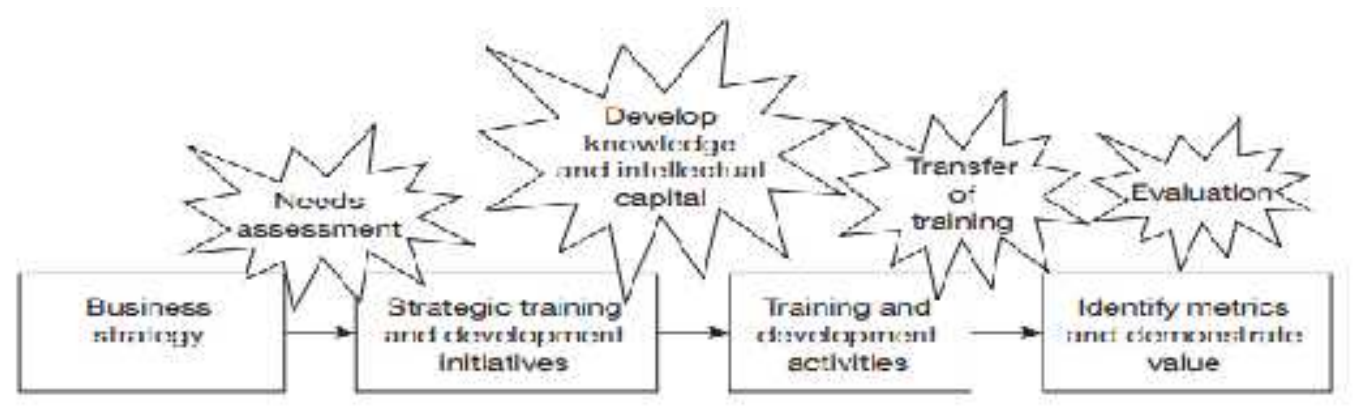

Gambar 1 Tahapan Stratejik dalam Pelatihan dan Pengembangan Sumber: Noe (2009)

Salah satu teori mengenai evaluasi training dikemukakan oleh Kirkpatrick (1967), yang dikenal dengan The Four Levels Techniques for Evaluating Training Programs. Kirkpatrick (1998) mengemukakan bahwa evaluasi suatu pelatihan merupakan bagian yang tidak dapat dipisahkan dari pelatihan itu sendiri dan evaluasi tersebut merupakan kegiatan yang harus dilakukan untuk mengetahui apakah pelatihan secara keseluruhan berlangsung secara efektif atau tidak. Menurut Kirkpatrick
(Tupamahu, 2005), ada empat tingkatan yang dilakukan dalam evaluasi pelatihan. Pertama, evaluasi pada reaksi/reaction (evaluasi level 1) yaitu evaluasi untuk mengukur reaksi kepuasan peserta terhadap pelaksanaan pelatihan. Kedua, evaluasi pada pembelajaran/learning (evaluasi level 2) yaitu evaluasi untuk mengukur sejauhmana peserta memahami materi pelatihan yang disampaikan dalam meningkatkan tiga kompetensi: pengetahuan (knowledge), ketrampilan (skill) dan 
sikap (attitude). Ketiga, evaluasi pada perilaku/behavior (evaluasi level 3) yaitu evaluasi untuk mengukur sejauhmana peserta menerapkan/mengimplementasikan pemahaman kompetensi yang diperolehnya tersebut dalam lingkungan pekerjaannya. Keempat, evaluasi pada hasil/result (evaluasi level 4) yaitu evaluasi untuk mengukur seberapa besar dampak pelaksanaan pelatihan terhadap kinerja pekerjaan ataupun hasil akhir yang diharapkan.

Pada prinsipnya, teori ini menyatakan bahwa proses evaluasi suatu training terdiri dari empat tingkat/level yaitu Level 1 sampai dengan Level 4, meskipun tidak sekuensial, saling terkait satu dengan lainnya. Teori ini telah banyak diterapkan dalam berbagai penelitian diantaranya Utomo (2014) yang melakukan evaluasi level 1, 2 dan 3 untuk mengukur efektivitas pelatihan ditinjau dari trainer dan materi yang disampaikan serta dampak pelatihan terhadap kinerja karyawan. Pengaruh in house training terhadap kompetensi guru juga dibuktikan oleh Maris(Maris, 2015). Beberapa penelitian terdahulu (Rukmi, Novirani, \& Sahrul, (Rukmi, 2014); Sutarto, (Sutarto, 2013)) juga menggunakan teori ini untuk melakukan evaluasi pada level 1 sampai dengan 4 untuk mengetahui pengaruh pelatihan terhadap produktivitas perusahaan.

\section{METODOLOGI PENELITIAN}

Penelitian ini dilakukan dengan tujuan untuk mengetahui bagaimana efektivitas pelatihan pada level II (learning) yang dise- lenggarakan oleh PSB UNJ. Definisi konseptual evaluasi pada pembelajaran/learning (evaluasi level 2) yaitu proses penilaian yang dilakukan untuk mengukur sejauhmana peserta memahami materi pelatihan yang disampaikan dalam meningkatkan kompetensi: pengetahuan (knowledge), ketrampilan (skill) dan perilaku (attitude). Skill mengukur sejauhmana ketrampilan yang diperoleh setelah mengikuti pelatihan.Knowledge mengukur sejauhmana pengetahuan yang diperoleh setelah mengikuti pelatihan. Dan attitude mengukur sejauhmana sikap dan perilaku mengalami perubahan setelah mengikuti pelatihan.

Populasi dalam penelitian ini, yaitu mahasiswa sebagai peserta pelatihan yang diselenggarakan oleh PSB UNJ. Jumlah mahasiswa yang mengikuti pelatihan pada periode penelitian adalah 160 mahasiswa yang berasal dari berbagai fakultas. Penentuan jumlah sampel menggunakan tabel Issac dan Michael dengan menggunakan taraf signifikansi $5 \%$, sehingga diperoleh sampel sebanyak 110 mahasiswa dari lima jenis pelatihan yang diteliti.Teknik pengambilan sampel yang digunakan adalah purposive sampling, dalam hal ini pengambilan sampel didasarkan pada pertimbangan yaitu mahasiswa yang mengikuti pelatihan di PSB UNJ. Sampel diambil secara proporsional berdasarkan jenis pelatihan yang dilaksanakan oleh PSB UNJ pada periode penelitian. Data yang digunakan dalam penelitian ini adalah data primer yang diperoleh 
melalui kuisioner dengan skala semantic 1 sampai 7 .

Hipotesis yang diajukan dalam penelitian ini adalah: (1) $\mathrm{H}_{0}=$ tidak terdapat perbedaan pengetahuan dan keterampilan mahasiswa antara sebelum mendapat pelatihan dengan setelah mendapatkan pelatihan, dan (2) $\mathrm{H}_{1}$ = terdapat perbedaan pengetahuan dan keterampilan mahasiswa antara sebelum mendapat pelatihan dengan setelah mendapatkan pelatihan.

\section{HASIL DAN PEMBAHASAN}

\section{Pelatihan Pembelajaran den- gan Pendekatan Saintifik}

Pelatihan pembelajaran dengan pendekatan saintifik memuat materi yang dimaksudkan untuk membekali mahasiswa dengan pengetahuan tentang kurikulum 2013, tujuan, prinsip-prinsip, tahapan, penilaian dan keterampilan menerapkan pendekatan saintifik. Berdasarkan data yang diperoleh dari sampel peserta pelatihan tentang pengetahuan mahasiswa mengenai materi yang disampaikan pada pelatihan tersebut diperoleh rata-rata jawaban mengenai pengetahuan tentang kurikulum 2013 sebelum mengikuti pelatihan menunjukkan pengetahuan responden yang cukup tinggi yaitu 5,5 dan mengalami peningkatan setelah mengikuti pelatihan. Nilai rata-rata pengetahuan responden mengalami peningkatan menjadi sebesar 6,3 atau dapat dikategorikan tinggi.

Secara umum pengetahuan responden tentang pengertian, tujuan, prinsip-prinsip, langkah- langkah, penilaian, serta ketrampilan menerapkan pendekatan saintifik masih dapat dikategorikan sedang dengan nilai rata-rata jawaban responden sebesar 4,8. Setelah mengikuti pelatihan pembelajaran dengan pendekatan saintifik masing masing responden merasakan adanya peningkatan pengetahuan. Hal ini didukung dengan adanya peningkatan nilai rata-rata menjadi berkisar antara 5.7 sampai dengan 6 pada masing-masing butir pernyataan yang ada. Mengacu pada jawaban responden untuk semua pernyataan diketahui nilai rata-rata skor total jawaban responden sebelum pelatihan sebesar 34,21 dan setelah diadakan pelatihan sebesar 40,79.

\section{Pelatihan pembelajaran ber- basis proyek}

Jawaban responden me-

ngenai pengetahuan tentang penilaian dalam pembelajaran berbasis proyek yang diberikan sebelum maupun setelah mengikuti pelatihan tidak mengalami perubahan. Rata-rata responden mem-berikan penilaian pada skala 5. Hal ini menunjukkan bahwa materi mengenai penilaian dalam pendekatan berbasis proyek perlu mendapatkan perhatian dalam pelatihan yang akan diberikan selanjutnya. Sedangkan untuk pernyataan yang mengukur keterampilan menerapkan pendekatan berbasis proyek mengalami peningkatan dari rata-rata jawaban sebesar 4.6 menjadi 5,6.rata-rata skor total jawaban responden sebelum adalah sebesar 33 dan setelah diadakan pelatihan sebesar 40. 
Rata-rata pengetahuan responden sebelum mengikuti pelatihan adalah sebesar 33 dan setelahdiadakan pelatihan sebesar 40. Hal ini dapat dikategorikan pada tingkat sedang.Selanjutnya skor total rata-rata yang diperoleh responden setelah mengikuti pelatihan dapat dikategorikan tinggi. Dengan demikian dapat disimpulkan bahwa pengetahuan responden setelah mengikuti pelatihan mengalami peningkatan.

\section{Pelatihan belajar berbasis internet}

Pelatihan belajar berbasis internet merupakan pelatihan yang diselenggarakan oleh PSB sebagai bentuk respon terhadap perubahan teknologi. Saat ini seorang guru harus memiliki keterampilan dalam menggunakan teknologi internet terutama dalam mencari sumber belajar yang lebih bervariasi. Berdasarkan hasil analisis data, diketahui bahwa rata-rata jawaban responden mengenai keterampilan mencari, mengambil, menyusun informasi dan menggunakan search engineberkisar pada nilai 6 atau dapat dikategorikan tinggi pada saat sebelum mengikuti pelatihan belajar berbasis internet.Sementara setelah mengikuti pelatihan tersebut ratarata jawaban responden meningkat menjadi sangat tinggi. Demikian juga untuk pernyataan mengenai ketrampilan memilih informasi dari berbagai sumber belajar, rata-rata jawaban responden mengalami peningkatan dari 5.7 menjadi 7 . Atau dapat dikatakan keterampilan meningkat dari kategori cukup tinggi menjadi tinggi.
Nilai rata-rata skor total jawaban responden sebelum pelatihan adalah sebesar 29 dan setelah diadakan pelatihan sebesar 33. Mengacu pada analisis data maka rata-rata pengetahuan reponden sebelum dan sesudah mengikuti pelatihan dikategorikan pada tingkat tinggi. Dengan demikian dapat disimpulkan bahwa pengetahuan tentang materi yang diberikan saat pelatihan belajar berbasis internet sudah tinggi sehingga pada masa yang akan datang perlu dikaji kembali terkait dengan materi yang akan diberikan kepada mahasiswa yang mengikuti pelatihan belajar berbasis internet.

\section{Pelatihan Media Sederhana}

Dari sepuluh butir pernyataan yang diberikan untuk mengetahui pengetahuan dan ketrampilan membuat serta menggunakan media sederhana seperti flip chart, flash card dan media sederhana lainnya, rata-rata jawaban responden memberikan skor yang sama sebesar 4 untuk masingmasing pernyataan yang diukur sebelum mengikuti pelatihan. Sementara setelah mengikuti pelatihan tersebut rata-rata jawaban responden meningkat menjadi sebesar 5 . Peningkatan pengetahuan dan keterampilan yang secara umum tidak mengalami perubahan yang banyak, rata-rata jawaban responden mengalami peningkatan dari 4 menjadi 5 . Namun peningkatan pengetahuan dan ketrampilan menggunakan media sederhana dalam tahapan selanjutnya akan diuji hipotesis untuk mengetahui apakah terdapat 
perbedaan yang signifikan antara pengetahuan sebelum mengikuti pelatihan dengan setelah mengikuti pelatihan.

Berdasarkan data nilai ratarata skor total jawaban responden sebelum adalah sebesar 43 dan setelah diadakan pelatihan sebesar 54. Mengacu pada pengelompokan data berdasar kategori yang terdapat dalam tabel diatas maka rata-rata pengetahuan reponden sebelum pada tingkat sedang. Selanjutnya skor total rata-rata yang diperoleh responden setelah mengikuti pelatihan dapat dikategorikan tinggi.

\section{Pelatihan penilaian otentik.}

Responden rata rata memberikan jawaban 5 untuk pernyataan mengenai pengetahuan tentang penilaian otentik, kinerja, proyek, portofolio dan tertulis. Pernyataan tentang keterampilan membuat rubrik penilaian, memanfaatkan instrument tes uji petik kerja, tes unjuk kerja, tes tertulis dan keterampilan memanfaatkan penilain otentik dinilai responden dengan rata-rata jawaban 5.Hal ini menunjukkan bahwa pengetahuan dan keterampilan responden tentang penilaian otentik tergolong cukup tinggi.
Setelah mengikuti pelatihan, responden memberikan penilaian terhadap sepuluh pernyataan tersebut dengan rata-rata jawaban berkisar antara 5,8 sampai 6 . Terdapat peningkatan pengetahuan dan keterampilan responden tentang penilaian otentik setelah mengikuti pelatihan.Pelatihan penilaian otentik memiliki jumlah butir pernyataan valid sebanyak 10 butir. Berdasarkan data yang diperoleh, diketahui nilai rata-rata skor total jawaban responden sebelum adalah sebesar 48 dan setelah diadakan pelatihan sebesar 58. Mengacu pada pengelompokan data berdasar kategori yang terdapat dalam tabel diatas maka rata-rata pengetahuan reponden sebelum mengikuti pelatihan dapat dikategorikan pada tingkat sedang.Selanjutnya skor total ratarata yang diperoleh responden setelah mengikuti pelatihan dapat dikategorikan tinggi.Dengan demikian dapat disimpulkan bahwa pengetahuan responden setelah mengikuti pelatihan mengalami peningkatan.

Hasil pengujian hipotesis dengan menggunakan uji $t$ pada masing-masing pelatihan yang diselenggarakan oleh PSB UNJ disajikan pada tabel 1 sebagai berikut:

Tabel 1. Uji t untuk sampel berpasangan

\begin{tabular}{l|c|c|c}
\hline \multicolumn{1}{c|}{ Variabel } & t value & Sign.Prob & df \\
\hline Pelatihan pembelajaran dengan & $-4,527$ & 0.001 & 13 \\
pendekatan scientifik & & & \\
\hline Pelatihan pembelajaran berbasis proyek & -12.592 & 0.000 & 22 \\
\hline Pelatihan berbasis internet & -8.227 & 0.000 & 26 \\
Pelatihan media sederhana & -7.076 & 0.000 & 24 \\
Pelatihan penilaian otentik & -6.771 & 0.000 & 20 \\
\hline
\end{tabular}


human

resource

management, 262-284.

Rukmi, H. S. (2014). Evaluasi

Training Dengan

Menggunakan Model

Kirkpatrick (Studi Kasus

Training Foreman

Development Program Di PT.

Krakatau Industrial Estate

Cilegon). the 5th National

Industrial Engineerin.

Sutarto, H. (2013). Strategi

Penggeseran Paradigma

Pelatihan dari Orientasi

Aktivitas di Kelas ke Hasil di

Tempat Kerja. Jurnal

Cakrawala Pendidikan(2).

Tannenbaum, S. (2002). A strategic view of organizational training and learning. Creating, implementing, and managing effective training and development, 10-52.

Tupamahu, S. \&. (2005).

Pengukuran Return on

Training Investement (ROTI).

Majalah USAHAWAN.

Utomo, A. P. (2014). Evaluasi

Pelatihan dengan Metode

Kirkpatrick Analysis. Jurnal

Telematika, 9(2), 37. 